\title{
The Effect of Sleep Duration on Overweight or Obesity in Female Adolescents: A Meta-Analysis Study
}

\author{
Putri Isriyatil Jannah'), Eti Poncorini Pamungkasari 2), Hanung Prasetya ${ }^{3}$ ) \\ ${ }^{1)}$ Masters Program in Public Health, Universitas Sebelas Maret \\ 2)Faculty of Medicine, Universitas Sebelas Maret \\ 3)Acupuncture Study Program, Health Polytechnic Ministry of Health Surakarta
}

\section{ABSTRACT}

Background: Overweight or obesity is a condition of excessive accumulation of fat in the body which is indicated by a Body Mass Index value exceeding $25 \mathrm{~kg} / \mathrm{m}^{2}$. WHO estimated that in 2022 adolescents will experience more obesity cases than underweight cases. One of the behaviors that can reduce the risk of overweight and obesity is having adequate sleep duration. This study aimed to analyze the magnitude of the effect of sleep duration on overweight or obesity in female adolescents with a metaanalysis study.

Subjects and Method: This was a systematic review and meta-analysis study. The study was carried out by following the PRISMA diagram. The process of the search for articles through a database that included: PubMed, Google Scholar, and Springer Link. The articles were selected in the period 2009-2020. The keywords used include: "sleep duration" AND adolescents, overweight AND "female adolescents", obesity AND adolescent, "sleep duration" OR "overweight obesity" OR adolescents OR "cross-sectional", "sleep duration" AND "overweight obesity "AND adolescent," sleep timing "AND obesity AND girls. The inclusion criteria were full-text articles with cross- sectional study design, English and Indonesian articles, and articles that used multivariate analysis with adjusted Odds Ratio. The articles that qualify were analyzed using the Review Manager 5.3 application.

Results: A total of 9 primary articles from Korea, China, and the USA had conducted a meta-analysis with a sample of 104,726 female adolescents. The results of the meta-analysis showed that female adolescentswith short sleep duration had a risk of overweight or obesity 1.44 times compared with female adolescents with long sleep duration $(\mathrm{aOR}=1.44,95 \% \mathrm{CI}=$ 1.24 to $1.69, \mathrm{p}<0.001$ ).

Conclusion: Short sleep duration significantly increases overweight/obesity in female adolescents.

Keywords: duration of sleep, overweight or obesity, female adolescents

\section{Correspondence:}

Putri Isriyatil Jannah. Masters Program in Public Health, Universitas Sebelas Maret. Jl. Ir. Sutami 36A, Surakarta 57126, Central Java, Indonesia. Email: putriisriyatil@gmail.com. Mobile: 089634956745 .

\section{Cite this as:}

Jannah PI, Pamungkasari EP, Prasetya H (2021). The Effect of Sleep Duration on Overweight or Obesity in Female Adolescents: A Meta-Analysis Study. Indones J Med. 06(01): 52-62. https://doi.org/10.26911/theijmed.2021.06.01.06.

(i) (-) Indonesian Journal of Medicine is licensed under a Creative Commons

EY NG SA Attribution-NonCommercial-ShareAlike 4.0 International License.

\section{BACKGROUND}

Adolescent according to the World Health Organization (WHO) is someone who is in the age range of 10-19 years. The increasing prevalence of overweight and obesity in adolescents did not only occur in developed countries but also occurred in developing countries. The incidence of obesity in children and adolescents that occupied the global level had increased from 11 million people in 1975 to 124 million people in 2015 (Lobstein et al., 2015). 
According to WHO data, it was estimated that in 2022 more cases of obesity will be experienced by children and adolescents than underweight cases (Lopez et al., 2020). The prevalence of obesity in children and adolescents in

America was $18.5 \%$ or about 13.7 million children and adolescents. Adolescents aged 12-19 years were around 20.6\% (CDC, 2020). The results of a study performed by Lobstein (2010) in MachadoRodrigues (2012) stated that cases of overweight and obesity in children and adolescents in North America were $>30 \%$, the cases in Australia were 21\%-25\%, and about $20 \%$ of cases occurred in Europe. Basic Health Research data in 2013 in Indonesia showed that adolescents aged 13-15 experience an incidence of overweight and obesity by $8.3 \%$ and $2.5 \%$ (Kemenkes RI, 2013).

Adolescence should become an important period in life to improve health status. Various behaviors that adolescents can do to improve their health, such as adequate physical activity, optimal and quality sleep duration, and proper food intake (Kracht et al., 2020). The sleep duration guidelines recommended by The National Sleep Foundation are 9-11 hours per night for adolescent age 10-13 years and 8-10 hours per night for ages 14-17 years (Hirshkowitz et al., 2015).

Sufficient sleep duration can help to start the day well and not easily get drowsy during the day. Therefore, a person can perform physical activity or other activities optimally to prevent overweight and obesity (Stefan et al., 2018). Sleep becomes something essential that can improve health. It is due to the fulfillment of sleep duration and good quality of sleep that can activate the immune system, increase the balance of metabolism and body hormones, improve mental and emotional health, and improve the memory process (Bonanno et al., 2019).

Larsen et al. (2020) argued that low sleep duration is associated with a high Body Mass Index (BMI) numbers. Some previous studies had also suggested similar things regarding sleep duration and the incidence of overweight or obesity in adolescents. Longitudinal studies that had been conducted in the past had objectively shown that sufficient and consistent sleep duration could be an effort to prevent overweight and obesity.

Based on some of the results of the study above, it was stated that the incidence of overweight and obesity in female adolescents was caused by short sleep duration. This study aimed to analyze the influence of sleep duration on overweight or obesity in female adolescents.

\section{SUBJECTS AND METHOD}

\section{Study Design}

This was a meta-analysis study. The search for articles was conducted for one month systematically and comprehensively through databases including PubMed, Google Scholar, and Springer Link. The keywords used: "sleep duration" AND adolescents, AND overweight AND "female adolescents", obesity AND adolescents, OR "sleep duration" OR "overweight obesity" OR adolescents OR "cross-sectional", "sleep duration" AND "overweight obesity "AND adolescent, AND obesity AND girls.

\section{Inclusion Criteria}

The inclusion criteria in the study were articles in English and Indonesian, articles with a cross-sectional study design, full-text articles with a period of 11 years, a sample of female adolescents aged 10-19 years, indicators of obesity in the form of BMI $\geq$ $25 \mathrm{~kg} / \mathrm{m}^{2}$, female adolescents doing physical activity $\leq 60$ minutes per day, 
andfemale adolescents with sleep duration $\leq 7$ hours per night.

\section{Exclusion Criteria}

The exclusion criteria in this study were articles with experimental study design, non-full-textarticles, cross-sectional articles that did not include the adjusted odds ratio (aOR), the outcome of the articles was not overweight/obesity, and articles thatused descriptive analysis, systematic review, and meta-analysis study design.

\section{Operational Definition of the Study}

The article search was carried out by considering the eligibility criteria defined using the PICO model. The population in the study were female adolescentswith the interventions were in the form of short sleep duration, the comparison was long sleep duration, and the outcome was in the form of overweight/obesity.

Overweight/obesity was overweight and obesity was a condition of excessive accumulation of fat in the body characterized by a BMI size of $\geq 25 \mathrm{~kg} / \mathrm{m}^{2}$. The instruments were in the form of a calibrated microtoice and weight scale. The measurement scale was a continuous scale.

Sleep duration was a condition of a person who was not responsive to the external environment which functioned to rest the body's organs and limbs for less than 7 hours per night in a 24 hours. The instrument used was a self-questionnaire with a continuous measurement scale.

\section{Data Analysis}

The articles were identified using the PRISMA diagramand analyzed using the Review Manager 5.3 application by calculating the effect size and heterogeneity to determine which research models were combined to form the final meta-analysis result.

\section{RESULTS}

The process of reviewing articles can be seen in Figure 1. The PRISMA diagram meta-analysis analyzed 9 primary studies conducted in America and Asia.

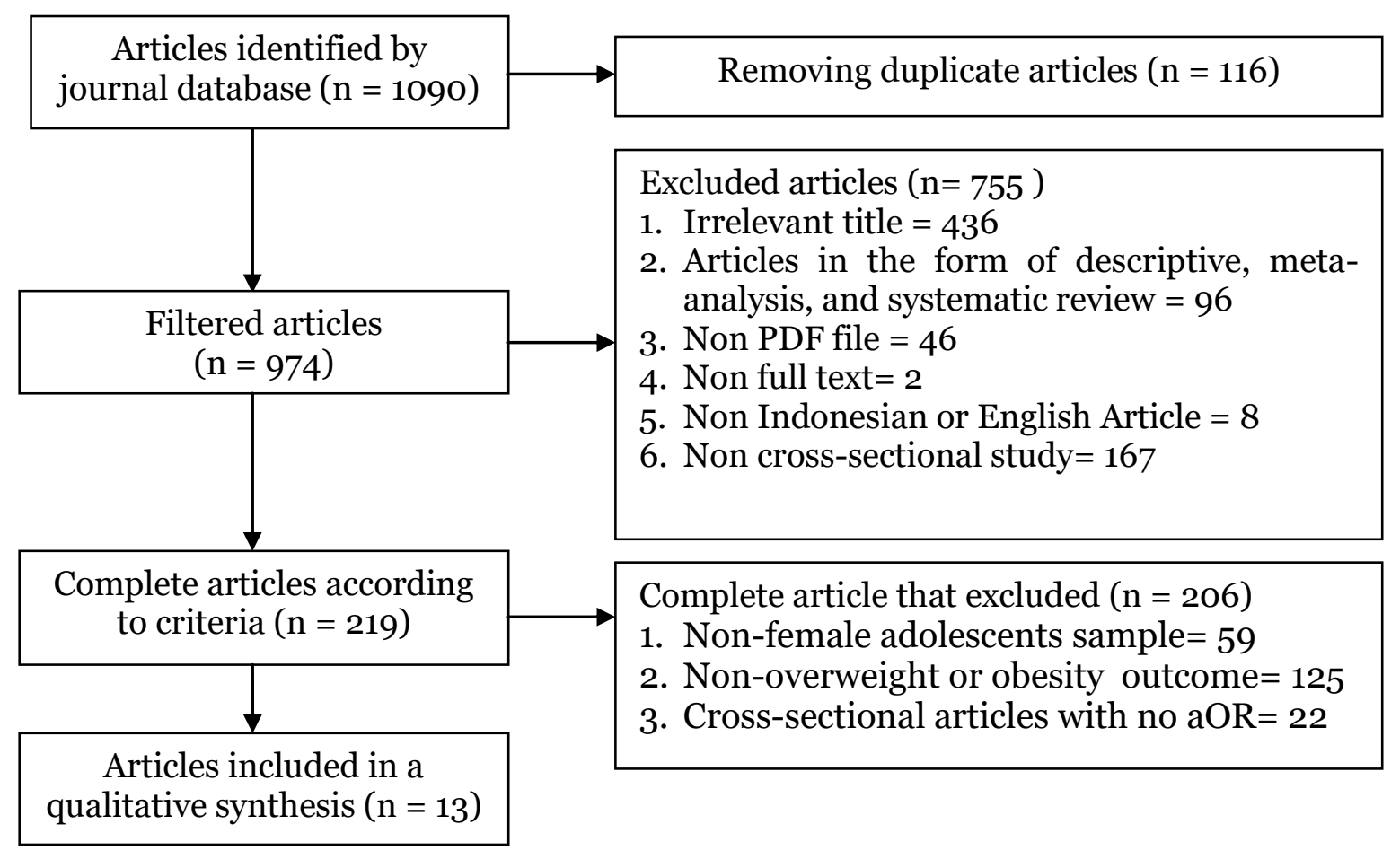

Figure 1. PRISMA diagram 
Jannah et al./ The Effect of Sleep Duration on Overweight or Obesity

The study quality assessment was carried out quantitatively. This study used an assessment of the quality of research studies for the cross-sectional design of the Center for Evidence-Based Management (CEBMa) in 2014.

Table 1. The assessment of research quality in cross-sectional studies

\begin{tabular}{lccccccccccccc}
\hline \multicolumn{1}{c}{$\begin{array}{c}\text { Primary Study } \\
\text { (Author and Year) }\end{array}$} & $\mathbf{1}$ & $\mathbf{2}$ & $\mathbf{3}$ & $\mathbf{4}$ & $\mathbf{5}$ & $\mathbf{6}$ & $\mathbf{7}$ & $\mathbf{8}$ & $\mathbf{9}$ & $\mathbf{1 0}$ & $\mathbf{1 1}$ & $\mathbf{1 2}$ & Total \\
\hline Kong et al. (2015) & 1 & 1 & 1 & 0 & 1 & 1 & 1 & 1 & 1 & 1 & 0 & 1 & 10 \\
Hahn et al. (2018) & 1 & 1 & 1 & 0 & 1 & 1 & 1 & 1 & 1 & 1 & 0 & 1 & 10 \\
Laurson et al. (2015) & 1 & 1 & 1 & 0 & 1 & 1 & 1 & 1 & 1 & 1 & 0 & 1 & 10 \\
Lowry et al. (2012) & 1 & 1 & 1 & 0 & 1 & 1 & 1 & 1 & 1 & 1 & 0 & 1 & 10 \\
Lee et al. (2014) & 1 & 1 & 1 & 1 & 1 & 1 & 1 & 1 & 1 & 1 & 0 & 1 & 10 \\
Grandner et al. (2015) & 1 & 1 & 1 & 0 & 1 & 1 & 1 & 1 & 1 & 1 & 0 & 1 & 10 \\
Wang et al. (2018) & 1 & 1 & 1 & 0 & 1 & 1 & 1 & 1 & 1 & 1 & 0 & 1 & 10 \\
Gong et al. (2018) & 1 & 1 & 1 & 0 & 0 & 1 & 1 & 1 & 1 & 1 & 0 & 1 & 9 \\
Seo et al. (2019) & 1 & 1 & 1 & 0 & 1 & 0 & 1 & 1 & 1 & 1 & 0 & 1 & 9 \\
\hline
\end{tabular}

\section{The Effect of Short Sleep Duration on Overweight / Obesity}

There were 9 articles about the effect of low sleep duration on overweight and obesity in female adolescents as follows:

\section{a. Forest plot}

The effect between short sleep duration and the incidence of overweight/obesity in female adolescents is shown in the results of the forest plot in Figure 2.
Odds Ratio

Study or Subgroup $\log [$ Odds Ratio] SE Weight IV, Random, $95 \% \mathrm{Cl}$

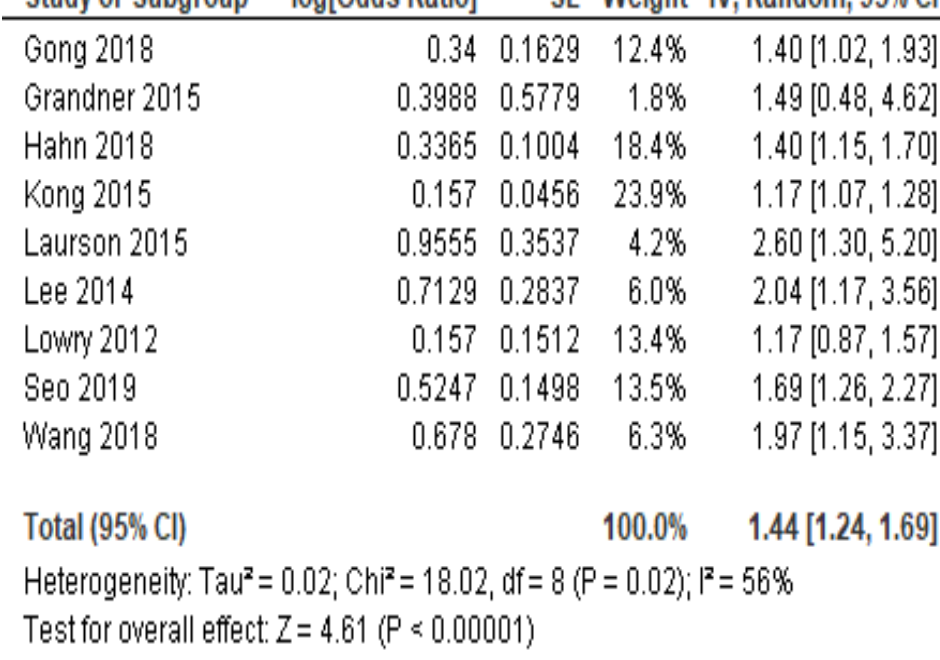

Odds Ratio IV, Random, $95 \% \mathrm{Cl}$

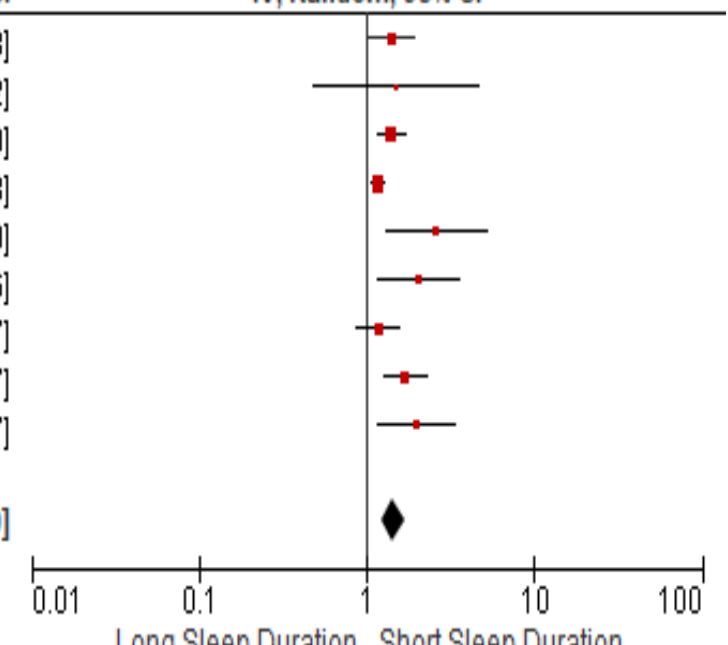

\section{Figure 2. Forest plot of the effect of short sleep duration on overweight/obesity in female adolescents}

\section{b. Funnel plot}

Figure 3 shows that there was publication bias due to the asymmetric distribution of the plot. Interpretation of the results from the meta-analysis process can be seen from the forest plot. Figure 2 shows that female adolescents who had short sleep duration increased the incidence of overweight/ obesity by 1.44 times compared to female adolescents who had long sleep duration $(\mathrm{aOR}=1.44,95 \% \mathrm{CI}=1.24$ to $1.69, \mathrm{p}$ $<0.001)$. The heterogeneity of the research data showed $\mathrm{I}^{2}=56 \%$, so that the distribution of the data was stated to be heterogeneous (random effect model). 
Table 2. Primary study descriptions were included in the meta-analysis

\begin{tabular}{|c|c|c|c|c|c|c|c|}
\hline $\begin{array}{l}\text { Author } \\
\text { (year) }\end{array}$ & Country & $\begin{array}{l}\text { Design } \\
\text { of the } \\
\text { Study }\end{array}$ & Sample & Population & $\begin{array}{c}\text { I } \\
\text { Intervention }\end{array}$ & $\begin{array}{c}\mathrm{C} \\
\text { Comparison }\end{array}$ & $\begin{array}{c}\text { O } \\
\text { Output }\end{array}$ \\
\hline $\begin{array}{l}\text { Kong et al. } \\
\text { (2015) }\end{array}$ & Korea & $\begin{array}{l}\text { Cross- } \\
\text { sectional }\end{array}$ & 53,769 & $\begin{array}{l}\text { Female } \\
\text { Adolescent } \\
\text { (12-18 years) }\end{array}$ & $\begin{array}{l}\text { Physical activity } \leq 60 \text { minutes } \\
\text { per day or the average activity } \\
\leq 2 \text { days, sitting time and } \\
\text { leisure sitting time accumu- } \\
\text { lated for a week } \geq 6 \text { hours and } \\
\geq 3 \text { hours a day. Sleep duration } \\
\text { of } \leq 7 \text { hours a day * }\end{array}$ & $\begin{array}{l}\text { Physical activity } \geq 60 \text { minutes } \\
\text { per day or the average activity } \\
\geq 2 \text { days, sitting time and leisure } \\
\text { sitting time accumulated for a } \\
\text { week } \leq 6 \text { hours and } \leq 3 \text { hours a } \\
\text { day. Sleep durationof } \geq 7 \text { hours } \\
\text { a day*. }\end{array}$ & $\begin{array}{l}\text { Overweight } \\
\text { and Obesity }\end{array}$ \\
\hline $\begin{array}{l}\text { Hahn et al. } \\
(2018\end{array}$ & $\begin{array}{l}\text { United } \\
\text { State }\end{array}$ & $\begin{array}{l}\text { Cross- } \\
\text { Sectional }\end{array}$ & 4,383 & $\begin{array}{l}\text { Female } \\
\text { Adolescent } \\
\text { (class 9-12) }\end{array}$ & $\begin{array}{l}\text { Fruit juice intake } \leq 2 \text { times a } \\
\text { day, vegetable consumption } \\
\leq 2 \text { times a day, physical } \\
\text { activity } \leq 60 \text { minutes per day } \\
\text { or less than } 5 \text { days, not having } \\
\text { breakfast every day, and } \\
\text { sleeping duration } \leq 7 \text { hours *. }\end{array}$ & $\begin{array}{l}\text { Fruit juice intake } \geq 2 \text { times a } \\
\text { day, vegetable consumption } \geq 2 \\
\text { times a day, physical activity } \\
\geq 60 \text { minutes per day or less } \\
\text { than } 5 \text { days, not having } \\
\text { breakfast every day, and } \\
\text { sleeping duration } \geq 7 \text { hours *. }\end{array}$ & $\begin{array}{l}\text { Overweight } \\
\text { and Obesity }\end{array}$ \\
\hline $\begin{array}{l}\text { Laurson et al. } \\
2015\end{array}$ & $\begin{array}{l}\text { United } \\
\text { State }\end{array}$ & $\begin{array}{l}\text { Cross- } \\
\text { Sectional }\end{array}$ & 4,874 & $\begin{array}{l}\text { Female } \\
\text { Adolescent } \\
(15-18 \text { years })\end{array}$ & $\begin{array}{l}\text { Physical activity } \leq 60 \text { minutes } \\
\text { per day and } 7 \text { days a week, } \\
\text { watching TV for } \geq 2 \text { hours and } \\
\text { sleep duration of } \leq 7 \text { hours * }\end{array}$ & $\begin{array}{l}\text { Physical activity } \geq 6 \text { o minutes } \\
\text { per day and } 7 \text { days a week, } \\
\text { watching TV for } \leq 2 \text { hours and } \\
\text { sleep duration of } \geq 7 \text { hours *. }\end{array}$ & $\begin{array}{l}\text { Overweight } \\
\text { and Obesity }\end{array}$ \\
\hline $\begin{array}{l}\text { Lowry et al. } \\
2012\end{array}$ & $\begin{array}{l}\text { United } \\
\text { State }\end{array}$ & $\begin{array}{l}\text { Cross- } \\
\text { Sectional }\end{array}$ & 23,579 & $\begin{array}{l}\text { Female } \\
\text { Adolescent } \\
\text { (class 9-12) }\end{array}$ & $\begin{array}{l}\text { Sleep duration less than } 7 \\
\text { hours * }\end{array}$ & $\begin{array}{l}\text { Sleep duration more than } 7 \\
\text { hours * }\end{array}$ & $\begin{array}{l}\text { Overweight } \\
\text { and Obesity }\end{array}$ \\
\hline Park et al. 2014 & Korea & $\begin{array}{l}\text { Cross- } \\
\text { Sectional }\end{array}$ & 1,187 & $\begin{array}{l}\text { Female } \\
\text { Adolescent } \\
\text { (12-18 years) }\end{array}$ & $\begin{array}{l}\text { Sleep duration of } \leq 7 \text { hours *, } \\
\text { a metabolic syndrome } \\
\text { consisting of high cholesterol } \\
\text { and triglycerides. }\end{array}$ & $\begin{array}{l}\text { Sleep duration of } \geq 7 \text { hours } * \text {, a } \\
\text { metabolic syndrome consisting } \\
\text { of high cholesterol and } \\
\text { triglycerides }\end{array}$ & $\begin{array}{l}\text { Overweight } \\
\text { and Obesity }\end{array}$ \\
\hline $\begin{array}{l}\text { Grandner et al. } \\
2015\end{array}$ & $\begin{array}{l}\text { United } \\
\text { State }\end{array}$ & $\begin{array}{l}\text { Cross- } \\
\text { Sectional }\end{array}$ & 272 & $\begin{array}{l}\text { Female } \\
\text { Adolescent } \\
\text { (16-17 years) }\end{array}$ & Sleep duration of $\leq 7$ hours * & Sleep duration of $\geq 7$ hours & $\begin{array}{l}\text { Overweight } \\
\text { and Obesity }\end{array}$ \\
\hline
\end{tabular}




\begin{tabular}{|c|c|c|c|c|c|c|c|}
\hline $\begin{array}{c}\text { Author } \\
\text { (year) }\end{array}$ & Country & $\begin{array}{l}\text { Design } \\
\text { of the } \\
\text { Study }\end{array}$ & Sample & Population & $\begin{array}{c}\text { I } \\
\text { Intervention }\end{array}$ & $\begin{array}{c}\mathrm{C} \\
\text { Comparison }\end{array}$ & $\begin{array}{c}\text { O } \\
\text { Output }\end{array}$ \\
\hline $\begin{array}{l}\text { Wang et al. } \\
2018\end{array}$ & China & $\begin{array}{l}\text { Cross- } \\
\text { Sectional }\end{array}$ & 9,259 & $\begin{array}{l}\text { Female } \\
\text { Adolescent } \\
\text { (rata-rata } 15 \\
\text { years }\end{array}$ & Sleep duration of $\leq 7$ hours * & Sleep duration of $\geq 7$ hours & $\begin{array}{l}\text { Overweight } \\
\text { and Obesity }\end{array}$ \\
\hline $\begin{array}{l}\text { Gong et al. } \\
2018\end{array}$ & China & $\begin{array}{l}\text { Cross- } \\
\text { Sectional }\end{array}$ & 1,355 & $\begin{array}{l}\text { Female } \\
\text { Adolescent } \\
\text { (12-13 years) }\end{array}$ & $\begin{array}{l}\text { Sleep duration of } \leq 7 \text { hours per } \\
\text { day }\end{array}$ & Sleep duration of $\geq 7$ hours & $\begin{array}{l}\text { Overweight } \\
\text { and Obesity }\end{array}$ \\
\hline Seo et al. 2019 & Korea & $\begin{array}{l}\text { Cross- } \\
\text { Sectional }\end{array}$ & 6,048 & $\begin{array}{l}\text { Female } \\
\text { Adolescent } \\
\text { (10-18 years) }\end{array}$ & $\begin{array}{l}\text { The duration of sleep aged 10- } \\
13 \text { years }<7 \text { hours and ages } 14- \\
18 \text { years }<6 \text { hours a day*, } \\
\text { cholesterol, blood sugar, and } \\
\text { HDL values increased from } \\
\text { normal limits. }\end{array}$ & $\begin{array}{l}\text { Sleep duration aged 10-13 } \\
\text { years }>7 \text { hours and ages 14-18 } \\
\text { years }>6 \text { hours a day }{ }^{*} \text {, } \\
\text { cholesterol, blood sugar, and } \\
\text { HDL values were within normal } \\
\text { limits }\end{array}$ & $\begin{array}{l}\text { Overweight } \\
\text { and Obesity }\end{array}$ \\
\hline
\end{tabular}

*Variables included in the meta-analysis 
The funnel plot in Figure 3. shows that there was a publication bias due to the distribution of the plot was not symmetrical. The left side of the diagram con- tained 4 plots with standard errors between o.o and 0.2. On the right side, there were 4 plots with standard errors between 0.2 and o.4. There was 1 plot located in the middle.

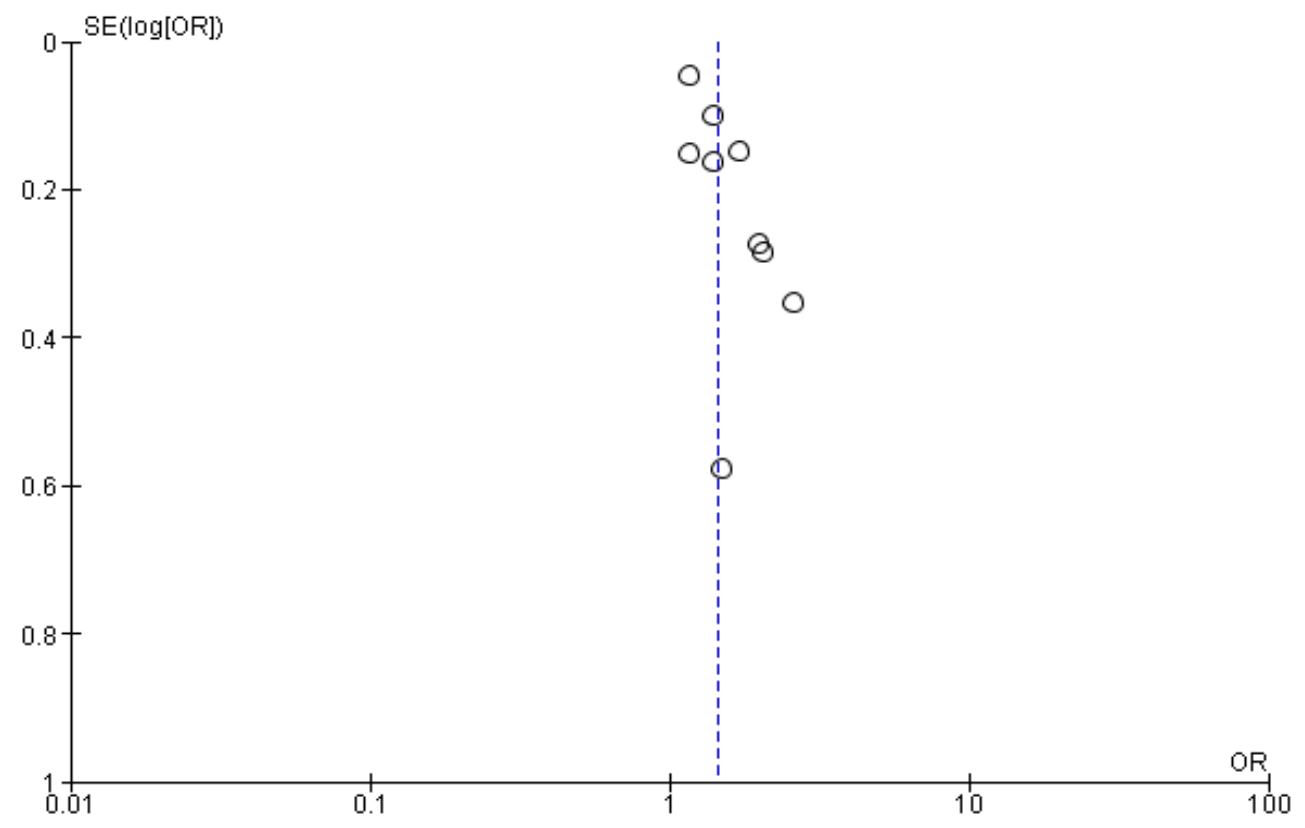

\section{Figure 3. Funnel plot of the effect of short sleep duration on overweight/obesity in female adolescents}

\section{DISCUSSION}

This Systematic review and meta-analysis study took the topic of factors that cause overweight and obesity in the 10-19 year old adolescent group. The factors used as independent variables in this study were low physical activity and short sleep duration. The outcome that became the dependent variable in this study was overweight or obesity. The study aimedto understand the magnitude of the effect of female adolescents who did the low physical activity and short sleep duration by using a metaanalysis study design.

The results of primary studies used for meta-data analysis were collected from various countries and in a large sample size so it could increase the heterogeneity of the results of the study. Besides, the metaanalysis study process had gone through the PRISMA stage which was a series of processes for identifying articles using database searches, filtering articles by determining inclusion and exclusion criteria, assessing the feasibility of primary studies, and selecting articles used for meta-analysis.

The articles that had been compiled through database searches were then entered into Mendeley's program to make the identification easier. This study collected 1,090 articles in the early stages of the PRISMA process. Furthermore, the duplicate data was deleted as many as 116 articles.There were 974 articles had been filtered then selected using the criteria determined by the researcher. The exclusion criteria determined by the researcher were descriptive/ systematic review/ metaanalysis articles, articles with no PDF files, irrelevant research titles, non-full text 
articles, and articles with no cross-sectional study designs.

The exclusion of articles at this stage was 755 files. Furthermore, the articles that had complete data were 219 articles, the exclusion process was carried out again with the sample criteria of non-female adolescents, the cross-sectional studies did not include aOR values, and the research outcome was not overweight/obesity. The results of the second exclusion were 206 articles, so the articles to be used for the meta-analysis were 13 articles. The quality of 13 articles was assessed using the CEBMa Critical Appraisal Checklist 2014 specifically for cross-sectional studies.

The Primary articles that had met the requirements then were analyzed using the Review Manager 5.3 program.The Data analysis was carried out one by one to find the influence of sleep duration on overweight/obesity in female adolescents.

The Effect of Short Sleep Duration on Overweight/ Obesity in Female Adolescents

The primary study used in the meta-analysis was 9 articles from Korea, the USA, and China. The study design was an observational cross-sectional. The results of the meta-analysis showed that there was a significant effect on femaleadolescents who had short sleep duration on increasing overweight/obesity by 1.44 times compared to femaleadolescents who had long sleep duration $(\mathrm{aOR}=1.44,95 \% \mathrm{CI}=1.24-1.69$, $\mathrm{p}<0.001)$.

This was supported by the important role of sleep for health and fitness. A recent study showed that sleep quality, sleep time could change a person's health condition. Sleep time that was not appropriate with the NSF's recommendations could lead to cardiovascular disease and death. Based on the results of a survey conducted by the National Health and Nutrition Examination from 2001 to 2005 , the risk of obesity could increase by $24 \%$ if the sleep duration less than 5 hours (Kim, 2017).

A person who had a short sleep duration could disrupt the secretion system of the hormones ghrelin and leptin. Short sleep duration could increase ghrelin secretion and inhibit leptin secretion. It could increase hunger and food intake at night (Knutson et al., 2008). This study is in line with the study performed by Vgontazas et al. (2008) that conducted on a large community sample, there was an association between a decrease in the hormone leptin and an increase in the hormone ghrelin when a person's sleep duration was not optimal and had a higher risk of increasing overweight and obesity.

The imbalance between the hormones leptin and ghrelin which is located in the hypothalamus when a person lacks sleep can affect hunger and increase energy intake (Ferranti et al. 2016). A cross-sectional study conducted on Australian adolescents showed that adolescents who had short sleep duration were at risk of being overweight or obese 1.47 times compared to adolescents who had normal sleep duration (Golley et al. 2013).

Short sleep duration caused sleep quality to be disturbed. This indirectly impacts decreased daily physical activity because the heart rhythm cycle is disrupted. Melatonin hormone decreases and anabolic hormone increases (Satriani et al, 2018).

Overweight in adolescents was influenced by efficacy. It was due to the perception of adolescents in self-control. Besides, self-control in adolescents was influenced by peers. If individuals have peers who support them to carry out activities, they can reduce the risk of obesity (Widiyanto et al. 2018). 


\section{AUTHOR CONTRIBUTION}

Putri Isriyatil Jannah was the principal researcher who selected topics, searched, and collected data of the study. Eti Poncorini Pamungkasari and Hanung Prasetya played a role in analyzing data and reviewing research documents.

\section{CONFLICT OF INTEREST}

There is no conflict of interest in this study.

\section{FUNDING AND SPONSORSHIP}

This study used a personal fund from the first researcher.

\section{ACKNOWLEDGEMENT}

We wouldlike to thank the database providers PubMed, Google Scholar, and Springer Link.

\section{REFERENCE}

Bonanno L, Metro D, Papa M, Finzi G, Maviglia A, Sottile F, et al. (2019). Assessment of sleep and obesity in adults and children. Medicine. 98 (46): 1-6. doi.org/10.1097/MD.ooo0000000017642.

CDC (2020). Consequences of obesity, more immediate health risks. https://www.cdc.gov/obesity/childhood/ca uses.html. Diakses Juli 2020.

Ferranti R, Marventano S, Castellano S, Giogianne G, Nolfo F, Rametta S, Metalone M, Mistretta A (2016). Sleep quality and duration is relate with diet and obesity in young adolescent living in Sicily, Southern Italy. Sleep Sci. 9(2): 117-122. doi: 10.1016/j.slsci.2016.04.003.

Golley R, Maher C, Matricciani L, Olds T (2013). Sleep duration or bedtime? Exploring the association between sleep timing behavior, diet and BMI in children and adolescents. Int $\mathrm{J}$ Obes. 34(4): 546-551. doi: 10.1038- /ijo.2012.212.

Hirshkowitz M, Whiton K, Albert S, Alessi C, Bruni O.(2015). National sleep foundation's sleep time duration recomendations: methodology and result summary. Sleep Health. 1(1): 40-43. doi.org/10.1016/j.sleh.2014.12.010.

Kementerian Kesehatan RI (2013). Pokokpokok Hasil Riset Kesehatan Dasar (Riskesdas) 2013 Provinsi Jawa Timur. Badan Penelitian dan Pengembangan Kesehatan Kementrian Kesehatan Republik Indonesia Tahun 2013.

Kim J. (2017). Sleep duration and obesity. J Obes Metab Syndr. 26(1): 1-2. doi.org/10.7570/jomes.2017.26.1.1.

Knutson K, Cauter V (2008). Associations between sleep loss and increased risk of obesity and diabetes. Ann N Y Acad Sci. 1129: 287-304.

Kracht C, Champagne C, Hsia D, Martin C, Newton R, Katzmarzyk P, Staiano A (2020). Association between meeting physical activity, sleep, and dietary guidelines and cardiometabolic risk factors and adiposity in adolescents. J Ado Health. 66(6): 733-739. doi.org/10.1016/j.jadohealth.2019.12.011.

Larsen S, Horgan G, Mikkelsen M, Palmeira A, Scott S, Duarte C, Santos I, Encantando J, Driscoll R, Turicchi J, Michalowska J, Stubbs J, Heitmann B (2020). Association between objectively measured sleep duration, adiposity and weight loss history. Int $\mathrm{J}$ Obes 1-9. doi: 10.1038/s41366-0200537-3.

Lobstein T, Leach R, Moodie M, Hall K, Gortmaker S, Swinburn B, James W, Wang Y (2015). Child and adolescent obesity: part of a bigger picture. Lancet. 385(9986): 2510-2520. doi:10.1016/So140-6736(14)61746-3.

Lobstein $\mathrm{T}$ (2010). Global prevalence of 
childhood obesity in Bouchard C and Katzmarzyk PT (eds) Physical Activity and Obesity. Champaign, IL: Human Kinetis.Chantry, Caroline J., Cynthia R. Howard, and Peggy Auinger. 2006. "Full Breastfeeding Duration and Associated Decrease in Respiratory Tract Infection in US Children." Pediatrics 117(2): 425-32.

Lopez P, Oliver A, Pihu M, Gisladittir T, Dominguez R, Ries F (2020). Association between adherence to the mediterranean diet and physical fitness with body composition parameters in 1717 European adolescents: the adoles health study. Nutrients. 12(77): 1-19. doi.org/10.3390/nu12010077.

Machado-Rodrigues A, Silva M, Mota J, Padez C, Ronque E, Cumming S, Malina R (2012). Cardiorespiratory fitness, weight status and objectively measured sedentary behaviour and physical activity in rural and urban Portuguese adolescents. J Child Health Care. 16(2): 166-177. doi: 10.1177/1367493511430676.

Satriani H, Indarto D, Dewi Y (2018). The path analysis of body mass index, physical exercise, sleep quality and parental education on physical fitness among male adolescences. $J$ Health Promot Behav. 3(4): 270-278. doi.org/10.26911/thejhpb.2018.03.04.07.

Stefan L, Sporis G, Kristicevic T, Knjaz D (2018). Associations between sleep quality and its domains and insufficient physical activity in alarge sample of Croatian young adults: across sectional study. BMJ. 8(7): 1-11. doi:10.1136/bmjopen-2018-021902.

Vgontzas A, Lin H, Papaliaga M, Calhoun S, Vela-Bueno A, Chrousos G, Bixler E (2008). Short sleep duration and obesity: the role of emotional stress and sleep disturbances. Int $\mathrm{J}$ Obes. 32: 801-809. doi:10.1038/ijo.2008.4.

Widiyanto A, Murti B, Soemanto (2018). Multilevel analysis on the effects of socio-cultural, lifestyle factors, and school environment, on the risk of overweight in adolescents, Karanganyar, District, Central Java. J Epidemiol Public Health. 3(1): 94-104. doi.org/10.26911/jepublichealth.2018.03.01 .08 . 